\title{
STUDI PENELUSURAN ALUMNI TEKNIK ELEKTRONIKA D3 SEBAGAI UPAYA PENINGKATAN MUTU PENYELENGGARAAN PROGRAM STUDI
}

\author{
Nuryake Fajaryati $^{1}$, Djoko Santoso ${ }^{2}$, Sri Waluyanti ${ }^{3}$ \& Ahmad Awaluddin Baiti ${ }^{4}$ \\ 1,2,3,4 UniversitasNegeri Yogyakarta \\ E-mail: nuryake@uny.ac.id
}

\begin{abstract}
This study aims to find out how the profile of graduates of D3 Electronics Engineering, alumni assessment about the quality of existing programs in Electronic Engineering D3, and the assessment of stakeholders on the competence of graduates. This research is an tracer study with quantitative descriptive analysis approach. Tracer study is done by concept of survey stage according to Schomburg. Sources of data are 55 alumni of D3 Electronic Engineering and 10 stakeholders. Data collection method is done by distributing questionnaires to alumni and stakeholders directly and through google doc. The results showed that the average GPA of the graduates for class of 2008-2014 was 3.27 and the duration of study 3 years 8 months. Most of them waiting gets job \pm 3 months. Assessment of alumni on administration services, learning aspects and experiences, involvement in research is good. The alumni assessment about the facilities is quite good. The stakeholders' assessment of the alumni in terms of integrity, science expertise, problem solving and communication skills, then cooperation are good. The ability of alumni in English is quite good.
\end{abstract}

Keywords: alumni, stakeholders, tracer study, D3 Electronic engineering

\begin{abstract}
ABSTRAK
Penelitian ini bertujuan untuk mengetahui profil lulusan Prodi D3 Teknik Elektronika, penilaian alumni mengenai mutu penyelenggaraan program yang ada di Prodi D3 Teknik Elektronika, dan penilaian stakeholders terhadap kompetensi lulusan.Penelitian ini merupakan tacer study dengan pendekatan analisis deskriptif kuantitatif. Pelaksanaan tracer study dilakukan dengan konsep tahapan survey menurut Schomburg. Sumber data penelitian yaitu 55 orang alumni Prodi D3 Teknik Elektronika dan 10 orang stakeholders. Metode pengumpulan data dilakukan dengan penyebaran kuesioner kepada alumni dan stakeholders secara langsung dan melalui google doc. Hasil penelitian menunjukkan rerata IPK lulusan prodi D3 Teknik Elektronika untuk angkatan 2008 - 2014 adalah 3,27 dan lama masa studi 3 tahun 8 bulan. Sebagian besar masa tunggu alumni mendapatkan pekerjaan \pm 3 bulan dengan pendapatan 1-3 juta/bulan. Penilaian alumni terhadap layanan administrasi, aspek pembelajaran, pengalaman belajar, dan keterlibatan dalam penelitian dan PPM termasuk baik. Sedangkan penilaian alumni tentang fasilitas perkuliahan cukup baik. Penilaian stakeholders terhadap alumni dalam hal integritas, keahlian bidang ilmu, kemampuan mengatasi permasalahan, kemampuan berkomunikasi, dan bekerjasama termasuk dalam kategori baik. sedangkan kemampuan alumni dalam berbahasa inggris tergolong cukup baik.
\end{abstract}

Kata kunci: alumni, stakeholders, tracer study, D3 Teknik Elektronika

\section{PENDAHULUAN}

Program studi (Prodi) D3 Teknik

Elektronika merupakan penyelenggara pendidikan bagian dari Fakultas Teknik Universitas negeri Yogyakarta (FT UNY) lembaga melaksanakan fungsi Tridarma Perguruan Tinggi, yaitu pendidikan, penelitian dan pengabdian kepada masyarakat, serta mengelola Ipteks selaras dengan bidang studi yang dikelolanya. Harus mampu melaksanakan fungsi Tridarma Perguruan Tinggi, yaitu pendidikan, penelitian dan pengabdian kepada masyarakat, serta mengelola Ipteks selaras dengan bidang studi 
yang dikelolanya. Untuk menopang dedikasi dan fungsi tersebut, program studi harus mampu mengatur diri sendiri dalam upaya meningkatkan dan menjamin mutu secara berkelanjutan, baik yang berkenaan dengan masukan, proses maupun keluaran program akademik dan layanan yang diberikan kepada masyarakat selaras dengan bidang studi yang dikelolanya.

Guna mendukung penjaminan mutu program studi, Kementerian Pendidikan Nasional (Kemdiknas) berkewajiban melakukan akreditasi bagi semua program studi dari semua institusi perguruan tinggi di seluruh Indonesia. Berdasarkan perundangundangan yang berlaku dan berbagai pertimbangan, Kemdiknas memberikan tanggung jawab pelaksanaan akreditasi program kepada Badan Akreditasi Nasional untuk Perguruan Tinggi (BAN-PT). Akreditasi program studi merupakan proses evaluasi dan penilaian secara komprehensif atas komitmen program studi terhadap mutu dan kapasitas penyelenggaraan program tridarma perguruan tinggi, guna menentukan kelayakan program studi untuk menyelenggarakan program akademiknya ${ }^{(1)}$.

Hasil akreditasi dapat dimanfaatkan sebagai dasar pertimbangan dalam transfer kredit perguruan tinggi, pemberian bantuan dan alokasi dana, serta pengakuan dari badan atau instansi yang lain. Oleh karena itu mutu prodi merupakan cerminan dari totalitas keadaan dan karakteristik masukan, proses, keluaran, hasil, dan dampak, atau layanan/kinerja program studi yang diukur berdasarkan sejumlah standar yang ditetapkan BAN-PT tersebut.

Berdasarkan uraian di atas dapat disimpulkan bahwa penting bagi perguruan tinggi sebagai pihak penyelenggara pendidikan tinggi dalam hal ini prodi untuk menjaga bahkan meningkatkan mutu penyelenggaraan prodi. Peningkatan mutu kualitas penyelenggaraan pendidikan dalam menciptakan lulusan yang berkualitas dapat terlaksana, jika sebuah Perguruan Tinggi mampu menciptakan atmosfer yang menunjang bagi terciptanya lingkungan institusi yang kondusif bagi terciptanya peningkatan penyelenggaran pendidikan dan lulusan secara berkesinambungan. PP No 19 Tahun 2005 menyatakan bahwa setiap perguruan tinggi dan program studi wajib terakreditasi (2). Artinya, pada pasal itu diwajibkan agar perguruan tinggi sungguhsungguh menyelenggarakan pendidikan tinggi berbasis mutu sehingga dapat menghasilkan SDM atau lulusan yang berkualitas dan siap kerja maupun siap menciptakan lapangan kerja di masyarakat.

Seberapa besar lulusan perguruan tinggi mampu berkiprah dan berkompeten dalam dunia kerja sesuai relevansi pendidikannya dapat dilakukan melalui studi penelusuran (tracer study). Menurut Bambang Setia Budi (3), sistem pendidikan yang baik memiliki alur sistem berbentuk putaran (loop) dimana tanggung jawab perguruan tinggi terhadap mahasiswa tidak berakhir pada saat kelulusan tetapi juga terkait keberlanjutan karier alumninya agar mereka lebih siap berkarya di tengah masyarakat. Tracer Study adalah wujud pertanggungjawaban untuk mengetahui peran alumninya di masyarakat. Alumni merupakan representasi perguruan tinggi, sehingga menjadi unsur yang tidak terpisahkan dari suatu perguruan tinggi ${ }^{(4)}$

Tracer study bertujuan untuk mengetahui hasil pendidikan dalam bentuk transisi dari dunia pendidikan tinggi ke dunia usaha dan industri, serta mengetahui bagaimana kinerja lulusan dalam dunia industri. Banyak faktor yang mempengaruhi kinerja seseorang. Menurut Gibson et al. dalam Trisnaningsih ${ }^{(5)}$ menyatakan bahwa kinerja karyawan merupakan suatu ukuran yang dapat digunakan untuk menetapkan perbandingan hasil pelaksanaan tugas, tanggung jawab yang diberikan oleh organisasi pada periode tertentu dan relatif dapat digunakan untuk mengukur prestasi kerja atau kinerja organisasi.

Selain yang telah dijabarkan di atas, tracer study memiliki peran penting lainnya, yaitu memberikan informasi penting untuk pengembangan perguruan tinggi, peningkatan 
mutu penyelenggaraan prodi, kepuasan mahasiswa terhadap penyelenggaraan prodi, berperan sebagai alat untuk mengevaluasi relevansi antara pendidikan tinggi dengan dunia kerja, dapat menyajikan masukan yang berguna bagi dosen dan administrator untuk peningkatan kinerja, serta masukan bagi para orangtua dalam memantau pendidikan anaknya.

Berbagai informasi penting tersebut dapat diketahui dari penilaian alumni terhadap penyelenggaraan prodi melalui studi penelusuran. Penilaian dari para alumni ini dapat menjadi evaluasi internal yang dapat digunakan untuk pengendalian dan peningkatan mutu penyelenggaraan pendidikan prodi. Oleh karena itu, penting bagi perguruan tinggi untuk melakukan penelitian dalam hal ini studi penelusuran alumni D3 Teknik Elektronika FT UNY sebagai upaya peningkatan mutu penyelenggaraan prodi.

\section{METODE}

Penelitian ini termasuk jenis penelitian penelusuran alumni (tracerstudy) dengan pendekatan analisis deskriptif kuantitatif Strategi yang dilakukan menggunakan survey. Menurut Schomburg ${ }^{(6)}$, ada tiga konsep tahapan survey dalam pelaksanaan tracer study yaitu tahap pengembangan konsep dan instrument, tahap pengumpulan data dan tahap analisa data serta penulisan laporan akhir. Lebih jelasnya dapat dilihat pada gambar 1 .

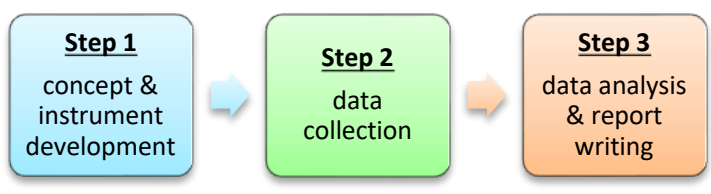

Gambar 1. Tahapan tracer study

Tahapan pengembangan konsep dan instrumen yang dilakukan meliputi, mendefinisikan tujuan, menentukan strategi survey yang akan dilakukan, merumuskan pertanyaan untukinstrumen, melakukan uji instrumen, dan memperbanyak instrumen yang akan dipakai.sedangkan tahapan pengumpulan data yang akan dilakukan yaitu, menyamakan persepsi anggota peneliti dalam hal teknik pengumpulan data, mendistribusikan instrumen, mengumpulkan dan mengorganisasi data dari alumni. Kemudian terakhir adalah tahapan analisis data dan penulisan laporan yang meliputi, memilah dan memilih data yang terkumpul (melakukan koding data), mengolah data, menyiapkan penulisan/pembuatan laporan akhir dan dilanjutkan seminar hasil penelusuran alumni (7).

Sumber data atau subyek dari penelitian ini adalah 55 orang alumni Prodi D3 Teknik Elektronika tahun 2013 - 2014 dan 10 orang stakeholders dari perusahaan BUMN, swasta, maupun lembaga pedidikan. Metode pengumpulan data yang dilakukan adalah survey dengan instrument angket. Penyebaran kuisioner/angket dilakukan kepada alumni dan stakeholders secara offline dan on line melalui telephon, sms, whatsapp, dan email. Secara offline, alumni dan stakeholders diminta secara langsung untuk mengisi angket yang disediakan, sedangkan bagi alumni yang mengisi angket secara online diakses pada link https://goo.gl/forms/GF2FM6Kty26EvSeu2.

sedangkan untuk stakeholders melaluilink https://goo.gl/forms/vAxuvIgU5S3DeW5il

Angket untuk alumni memuat tentang biodata diri, riwayat pekerjaan, penilaian alumni terhadap kualitas mutu penyelenggaraaan program studi yang meliputi, layanan administrasi, aspek pembelajaran, fasiltas perkuliahan, dan masukan bagi prodi D3 Teknik Elektronika. Sedangkan angket untuk stakeholders berisi penilaian stakeholders terhadap alumni yang meliputi integritas alumni (etika dan moral), keahlian berdasarkan bidang ilmu (profesionalisme), kemampuan dalam berbahasa inggris, penggunaan teknologi informasi, komunikasi, kerjasama tim, pengembangan diri, dan kemampuan alumni dalam mengikuti perkembangan IPTEK.

Metode analisis data yang digunakan dalam penelitian ini adalah teknik analsis deskriptif kuantitatif. Penilaian penyelenggaraan prodi D3 Teknik Elektronika oleh alumni dan penilaian stakeholders 
tentang keompetensi alumni diberikan lima alternatif pilihan untuk memberikan tanggapan yaitu; sangat baik dengan skor 5, baik dengan skor 4, cukup baik dengan skor 3, kurang baik dengan skor 2, dan sangat kurang baik dengan skor 1.

\section{HASIL DAN PEMBAHASAN}

Profil alumni yang didapatkan dari penelitian dapat dideskripsikan meliputi beberapa aspek. Rerata IPK lulusan Prodi D3 Teknik Elektronika untuk angkatan 2008-2014 adalah 3,27. Lama masa studi mahasiswa Prodi D3 Teknik Elektronika berdasarkan data tracer study rata-rata 3 tahun8 bulan. Berdasarkan data tracer study dapat diketahui bahwa masa tunggu lulusan dalam mendapatkan perkerjaan sebagian besar \pm 3 bulan.Macam-macam pekerjaan alumni dapat dilihat pada Tabel 1.

Tabel 1. Macam-macam pekerjaan alumni D3 Teknik Elektronika

\begin{tabular}{cccc}
\hline No. & Pekerjaan & Frekuensi & $\begin{array}{c}\text { Persentase } \\
(\%)\end{array}$ \\
\hline 1 & Karyawan & 13 & 23,64 \\
2 & swasta & 2 & 3,64 \\
3 & Operator BUMN & 2 & 1,82 \\
4 & Teknisi BUMN & 4 & 7,27 \\
5 & Teknisi swasta & 11 & 20,00 \\
6 & Instruktur & 1 & 1,82 \\
7 & BUMN & 1 & 1,82 \\
8 & Wiraswasta & 6 & 10,91 \\
9 & Guru SMK & 1 & 1,82 \\
10 & Lanjut S1 & 3 & 5,45 \\
11 & Belum bekerja & 12 & 21,82 \\
& & 55 & 100,00 \\
\hline
\end{tabular}

Kemudian untuk pendapatan alumni sebagian besar berkisar $1-3$ juta rupiah perbulan. Hal ini menunjukkan penghasilan alumni sebagian besar masih sebatas UMR.Dari data hasil penelitian tersebut dapat diambil kesimpulan bahwa alumni Prodi D3 Teknik Elektronika tidak mengalami banyak kesulitan dalam menyelesaikan studinya dan ini merupakan hal yang menggembirakan bagi Prodi. Kemudian setelah mereka lulus tidak terlalu lama dalam mendapatkan pekerjaan. Hal ini berarti kompetensi yang dimiliki oleh alumni diakui oleh dunia industri. Selain itu dengan waktu tunggu lulusan yang singkat secara tidak langsung dapat dikatakan bahwa inndustri banyak yang membutuhkan lulusan bidang teknik elektronika dan dengan direkrutnya alumni prodi D3 Teknik Elektronika membuktikan bahwa kompetensi yang dimiliki oleh para alumni diakui oleh dunia industri. Penilaian alumni tentang layanan administrasi yang dilakukan oleh tenaga administrasi program studi D3 Teknik Elektronika FT UNY termasuk dalam kategori baik. Sedangkan penilaian alumni tentang aspek pembelajaran yang ditekankan prodi D3 Teknik Elektronika FT UNY dalam hal tatap muka, diskusi, praktikum, partisipasi mahasiswa dalam riset, dan magang termasuk dalam kategori baik.

Penilaian alumni tentang aspek pembelajaran dalam hal proses belajar mengajar, bimbingan akademik, kesempatan berinteraksi dengan dosen di luar jam kuliah, dan kesempatan berpartisipasi dalam proyek risetdi prodi D3 Teknik Elektronika FT UNY termasuk dalam kategori baik. Penilaian alumni tentang fasilitas perkuliahan dalam hal kondisi ruang kuliah teori, sarana dan prasarana proses pembelajaran praktik, pemanfaatan media e-learning (be-smart), ketersediaan modul/bahan ajar, layanan perpustakaan fakultas, layanan perpustakaan prodi, layanan kesehatan bagi mahasiswa, serta pusat kegiatan mahasiswa di program studi D3 Teknik Elektronika FT UNY termasuk dalam kategori cukup baik.

Penilaian alumni tentang pengalaman belajar dalam hal proses pembelajaran di kelas, proses pembelajaran di bengkel/ laboratorium, penyelesaian tugas akhir, magang/Praktik Industri, kegiatan ekstrakurikuler, kegiatan organisasi kemahasiswaan, keterlibatan dalam pengabdian pada masyarakat (PPM), serta keterlibatan dalam penelitian di program studi 
D3 Teknik Elektronika FT UNY termasuk dalam kategori baik.

Pendapat alumni mengenai kualitas mutu penyelenggaraan program studi Teknik Elektronik D3 sebagian besar sudah baik. Akan tetapi ada hal-hal yang perlu ditingkatkan meliputi: (1) Peningkatan program kreativitas mahasiswa; (2) Materi yang disampaikan harus disesuaikan dengan kebutuhan industri; (3) Pembimbingan tugas akhir secara menyeluruh dan tidak hanya sistematika laporan; (4) Keterlibatan mahasiswa dalam riset/ penelitian; (5) Penambahan alat-alat penunjang praktik (alatalat dan bahan praktik ditambah dan diupdate). Hal tersebut dapat diupayakan oleh dosen melalui pengembangan alat bantu pembelajaran praktik untuk mengembangkan kemampuan pemahaman konsep dan pemecahan masalah ${ }^{(8)}$; dan (6) Pembelajaran berbasis proyek perlu diperbanyak. Selain itu, penilaian untuk layanan administrasi sebagian besar alumni D3 Teknik Elektronika berpendapat bahwa mutu layanan administrasi di prodi Teknik Elektronika D3 sudah baik akan tetapi ada beberapa hal yang perlu ditingkatkan, yaitu: kedisiplinan dalam pelayanan; dan keramahan dalam melayani mahasiswa.

Penilaian stakeholders terhadap alumni dalam hal integritas yang mencakup kejujuran, tanggungjawab, etos kerja, kemampuan menghargai oranglain, dan kemampuan menerima kritik dan saran termasuk dalam kategori baik. sedangkan penilaian stakeholders terhadap alumni tentang keahlian berdasarkan bidang ilmu yang meliputi penguasaan kompetensi teknik bidang ilmu, kemampuan penyelesaian masalah teknik di tempat kerja, dan kemampuan memanajemen waktu termasuk dalam kategori baik.

Penilaian stakeholders terhadap kemampuan berbahasa inggris alumni dalam hal kemampuan membaca teks berbahasa inggris, kemampuan menulis dalam bahasa inggris, dan menterjemahkan bahasa inggris ke bahasa indonesia termasuk dalam kategori baik. Akan tetapi penilaian tentang kemampuan berkomunikasi dengan bahasa inggris tergolong masih kurang baik.

Penilaian stakeholders pada alumni dalam hal komunikasi, yang meliputi komunikasi dengan teman sejawat, atasan, dan mitra kerja termasuk dalam kategori baik. Kemudian penilaian dalam hal kerjasama yang meliputi, kepatuhan terhadap keputisan bersama, kerjasama dengan teman sejawat, dengan atasan, dan mitra kerja juga tergolong baik. Penilaian stakeholders dalam hal pengembangan diri alumni yang meliputi mengikuti perkembagan iptek dan melakukan pelatihan bidang pekerjaan yang ditekuni termasuk dalam kategori baik.

\section{SIMPULAN}

Hasil penelitian menunjukkan bahwa rerata IPK lulusan prodi D3 Teknik Elektronika untuk angkatan 2008 - 2014 adalah 3,27 dan lama masa studi 3 tahun 8 bulan. Sebagian besar masa tunggu alumni dalam mendapatkan pekerjaan \pm 3 bulan dan bekerja sebagai karyawan swasta dan teknisi swasta dengan pendapatan 1-3 juta/bulan. Penilaian alumni terhadap layanan administrasi, aspek pembelajaran, pengalaman belajar, dan keterlibatan dalam penelitian dan PPM termasuk dalam kategori baik. sedangkan penilaian alumni tentang fasilitas perkuliahan tergolong cukup baik. Selain itu perlunya pembenahanantara lain: a) Peningkatan program kreativitas mahasiswa; b) Materi yang disampaikan harus disesuaikan dengan kebutuhan industri; c) Pembimbingan tugas akhir secara menyeluruh dan tidak hanya sistematika laporan; d) Keterlibatan mahasiswa dalam riset/ penelitian, e) Penambahan alat-alat penunjang praktik (alatalat dan bahan praktik ditambah dan diupdate); f) Pembelajaran berbasis proyek perlu diperbanyak

Penilaian stakeholders terhadap alumni dalam hal integritas, keahlian bidang ilmu, kemampuan mengatasi permasalahan, kemampuan berkomunikasi, dan bekerjasama 
termasuk dalam kategori baik. sedangkan kemampuan alumni dalam berbahasa inggris tergolong cukup baik.

\section{REFERENSI}

[1] Kemdiknas. Kajian Analisis Sistem Akreditasi Program Studi Dalam Rangka Reformasi Birokrasi Internal. s.l.: Kemdiknas, 2011.

[2] Nasional, Departemen Pendidikan. Peraturan Pemerintah Republik Indonesia Nomor 19 tahun 2005 tentang Standar Nasional pendidikan. Jakarta: Departemen Pendidikan Nasional, 2005.

[3] Budi, Bambang Setia. Tracer Study ITB 2016 Angkatan 2009. s.l. : ITB Career Center, 2016.

[4] Munir M., Wulandari, B., Dewanto, S.A., Pranoto, P.W., \& Utami, P. Tracer study prodi pendidikan teknik elektronika FT UNY sebagai kajian pengembangan kurikulum yang memiliki relevansi dengan kebutuhan dunia kerja. Yogyakarta : Prosiding Seminar Nasional ELINVO, 2015. 2477-2402.
[5] Trisnaningsih, Sri. Independensi Auditor Dan Komitmen Organisasi Sebagai Mediasi Pengaruh Pemahaman Good Governance, Gaya Kepemimpinan Dan Budaya Organisasi Terhadap Kinerja Auditor. s.1. : nhas Makassar, 26-28 Juli 2007. Universitas Pembangunan Nasional "Veteran", Jawa Timur, 2007.

[6] Schomburg, Harald. [Online] 2003. http://www.qtafi.de/handbook_v2.pdf..

[7] Sukardi, Thomas. Studi Penelusuran Lulusan S1 Kependidikan Fakultas Teknik Universitas Negeri Yogyakarta. 2, Yogyakarta: s.n., 2011, Jurnal Pendidikan Teknologi dan Kejuruan, Vol. 20.

[8] Utami, Pipit.Usaha penyiapan lulusan LPTK mellaui need assessment analysis alat bantu praktik instrumentasi. Yogyakarta: s.n., 2015. Seminar Nasional ELINVO. Vol. 1, pp. 101-113. 2477-2402. 